\title{
配電線への雷撃樣相の総合観測
}

\author{
正 員 平井 崇夫* 正 員 岡部 成光* \\ 正員 滝波 力* 正員珎道 拓治*
}

\section{Observation of Lightning Phenomena on Distribution Lines using Composite Techniques}

Takao Hirai*, Member, Shigemitsu Okabe*, Member,

Tsutomu Takinami*, Member, Takuji Chindo*, Member

\begin{abstract}
For the rationalization of lightning protection design of distribution lines, it is important to clarify the behavior of distribution line when direct or nearby lightning occurs. Because of the lower insulation level than is for transmission line, in study on lightning protection design of distribution line, not only direct lightning strokes but also induced voltages caused by nearby strokes must be taken into account. So it is necessary to grasp the frequency of occurrence on lightning phenomena around distribution lines. For this aim, lightning phenomena on TEPCO's distribution lines in use had been continuously observed for 6 years (1996-2001). The observation was carried out in composite way, using still-cameras and sensors for acquisition of lightning surge waveform data. Through the observation, new interesting phenomena about lightning performance on distribution lines in fields became apparent. In some case, in spite of direct striking to the line, flashover did not occur. This fact means that distribution line has a certain level of lightning resistance. Moreover, it was confirmed that AC following current generated between both ends of insulator disappeared naturally. These results are the interesting discoveries that can be useful to estimate the fault ratio precisely.
\end{abstract}

キーワード：雷，配電線，サージ，過電圧，事故，直撃雷，誘導雷

Keywords: lightning, distribution line, surge, overvoltage, fault, direct stroke, induced voltage

\section{1. まえがき}

配電設備は, 送変電設備に較べて機器の絶縁レベルが低 いため, 効果的な雷保護方式の検討や雷被害率の発生予測 に際しては, 直撃雷および配電線近傍への落雷により線路 に生じる誘導雷の双方を考慮に入れる必要がある(1)。近年 では, デジタルシミュレーション技術の発達を背景として， 電気幾何学モデル (2) における雷撃吸引距離の算定式を用い て, 配電設備への直撃雷と配電線近傍落雷による誘導雷の 発生頻度を㫕れ光れ算出することにより，配電線のフラッ シオーバ頻度を計算する検討もなされている ${ }^{(3)}$ 。しかしな がら，計算による雷事故率の值と実際の配電線雷事故率の 值との間には未だ隔たりがあり，雷フラッシオーバ頻度の 計算精度向上を図るためには, 実フィールドにおける配電線 への雷撃樣相の実態を把握する必要性か指摘されている ${ }^{(1)}$ 。

一般的に,配電線に雷事故が発生した場合，後日の現場調 査結果からだけでは, 弚の事故が直撃雷によるものか誘導

*東京電力 (株) 技術開発研究所絶縁技術グループ

厂 230-8510 横浜市鶴見区江ヶ崎町 4-1

Insulation Group. R\&D Center. TEPCO

4-1, Egasaki-cho, Turumi-ku, Yokohama 230-8510
雷によるものかを見分けるのは困難である。これは，上に 述べたように配電線の絶縁レベルでは誘導雷サージによっ ても絶縁破壞が発生する可能性があり，絶縁破壊した部分 に交流続流が流れてしまうことによる設備被害の樣相は直 撃雷・誘導雷いずれの場合も同樣であるためである。この ため, 実フィールドにおける直撃雷・誘導雷の発生比率を 把握するためには, カメラ等の光学系の観測装置が有効と されており,一部の電力会社においては, 自動撮影機能を 有する静止カメラを用いた配電線への雷撃樣相観測が行わ れている(4)。

筆者らは, 効果的な雷害対策手法の確立に向け, 静止型雷 観測カメラ (以下「雷観測カメラ」) による雷撃樣相観測お よび雷サージ波形観測装置 ${ }^{(5)}$ を用いた実配電線路へのを雷 撃現象の総合観測を実施してきた ${ }^{(6)}$ 。これらの観測を通じ て, 実配電線路への雷撃発生樣相や直撃雷・誘導雷発生時 の発生過電圧レベル等, 今後の配電線耐雷設計合理化に資 するデータを得た。このように, 営業用に供している実配 電線路においてカメラ観測とサージ波形観測を同時に行っ た例は，筆者らの知る限り本観測が初めてである。本論文 では光れらの成果のうち，1996 年〜2000 年の期間に得ら れた観測例について報告する。 


\section{2. 観測概要}

観測は，関東地方における雷の多発地帯である栃木県お よび群馬県内の 4 地域 (5 箇所) のエリアで実施した。観測 実施エリアを図 1 に示す。各観測エリアの面積は $1.4 \mathrm{~km}^{2}$ $3.4 \mathrm{~km}^{2}$,IKL 值は概ね2 28〜36である。各エリアには雷観測 カメラと雷サージ電圧・電流波形観測装置が光れぞれ 20

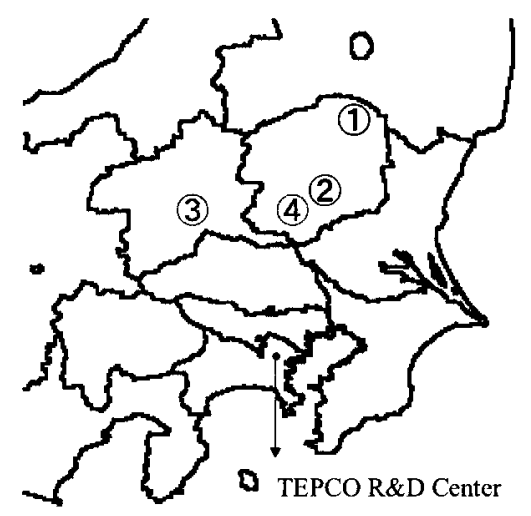

(1) Nasu (2)Utsunomiya (3)Isesaki (4)Tochigi

図 1 雷観測実施エリア

Fig. 1. Observation areas.

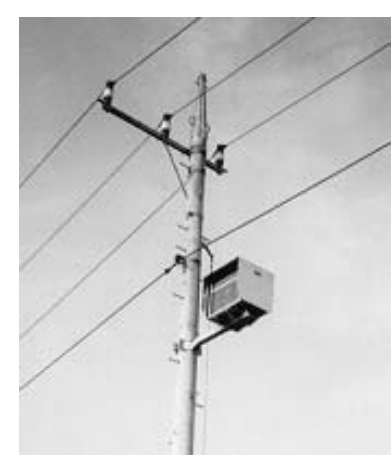

(a) Still camera

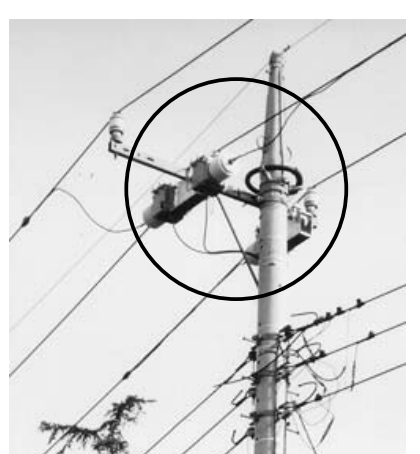

(b) Surge sensors

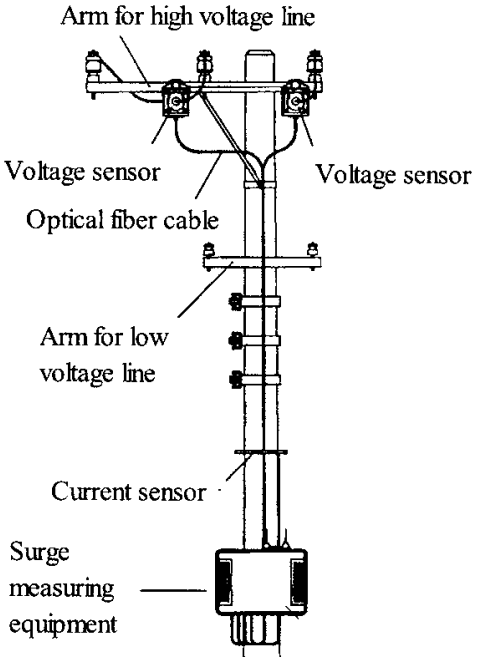

(c) Configuration of surge observation equipment

図 2 各種観測装置の取り付け状況

Fig. 2. Appearance of observation equipments.
30 台ずつ配置され，5 箇所のエリア合計で, 雷観測カメラ

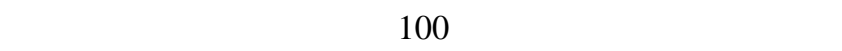
観測装置の説明を記す。また図 2 には, 各観測装置の配電 柱への取り付け状況を示す。

〈2 1 1 雷観測カメラ シャッター構成は, 通常の機 械式シャッターと，雷光を検知して自動的に動作する機構 を有する液晶シャッターの二段構成となっている。機械式 シャッターは, 1 回目の雷撃で動作すると以降開放状態と なり，2 回目の雷撃以降は液晶シャッターのみでの動作と なる。液晶シャッターは, 雷光検知後 $3 \mathrm{~ms}$ で完全解放とな り，1 回の開放時間は $250 \mathrm{~ms}$ である。各エリア内に配備さ れたカメラは, エリア内への落雷を複数で撮影できるよう 配置されており，2 台以上のカメラにより雷道が撮影され た雷については, 地図上で各カメラの撮影方向の交点を求 めることにより落雷位置の標定が可能である。

〈2 2 〉 雷サージ波形観測装置雷サージ波形観測装置 のセンサには, ロゴスキーコイルを用いた電流測定タイプ， および容量分圧器とポッケルス効果を用いた光変換素子か らなる電圧測定タイプの 2 種類があり，電圧センサは高圧 線の碍子間電圧を, 電流センサは電柱各部の接地線電流を 測定している。センサとデータ処理回路を含めた装置全体 の周波数応答特性は $250 \mathrm{~Hz} 250 \mathrm{kHz}$ で, 電圧タイプ・電 流タイプとも $1 \mu \mathrm{s}$ の波頭長を持つインパルス波形に対して 波高值計測誤差 5\%以内である。観測データは，センサの 取り付けられている電柱にマウントされている観測装置端 末にいったん保存された後, 毎日定時刻に携帯電話回線を 通じて東京電力技術開発研究所に設置されたパソコン内の データベースへ転送されるようになっている。なお，雷観 測カメラ, 雷波形観測装置ともに時刻校正部に GPS 時計を 用いているため, LPATS (落雷位置標定装置) ()の標定デー タとの照合による総合的な雷撃樣相の分析が可能となって いる。

\section{3. 観測結果}

1996 年〜2000 年までの期間内に観測された事例につい て, カメラ観測結果および同時に測定された雷サージ波形 観測データをもとに考察した結果を以下に述べる。なお， 以下において「閃絡」とは, 特にことわりのない限り碍子 部分での気中フラッシオーバを意味する。

〈3. 1〉直撃雷観測事例(1) 落雷の樣子をとらえた写真 を図 3 に , 観測現場の概況图を図 4 に示す。雷観測カメラ および雷波形観測装置の GPS 時計による雷撃時刻は, 1999 年 8 月 24 日 17:01:20であった。なお，この雷撃と同時刻 の変電所リレー動作はなかった。

(1) LPATS 標定データ カメラおよび雷波形観測装 置の GPS 時計による雷撃時刻と一致する LPATS 標定デー タを以下に示す。なお以下において「多重度」とは，観測 装置の測定データと, 標定時刻が $\pm 2 \mathrm{~s}$ 以内かつ標定位置が 半径 $2 \mathrm{~km}$ 以内の LPATS 落雷標定個数を意味する。

- 標定位置 : 雷撃柱の東南東約 $1.2 \mathrm{~km}$ 


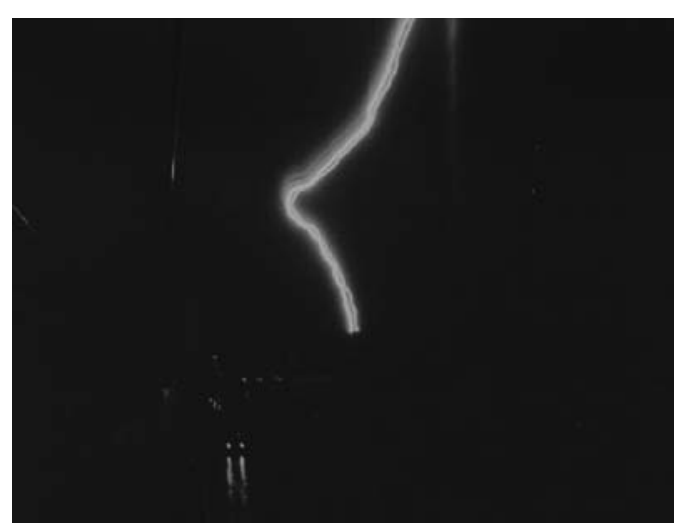

図 3 直撃雷観測写真炎の 1

Fig. 3. Photograph of direct stroke \#1.

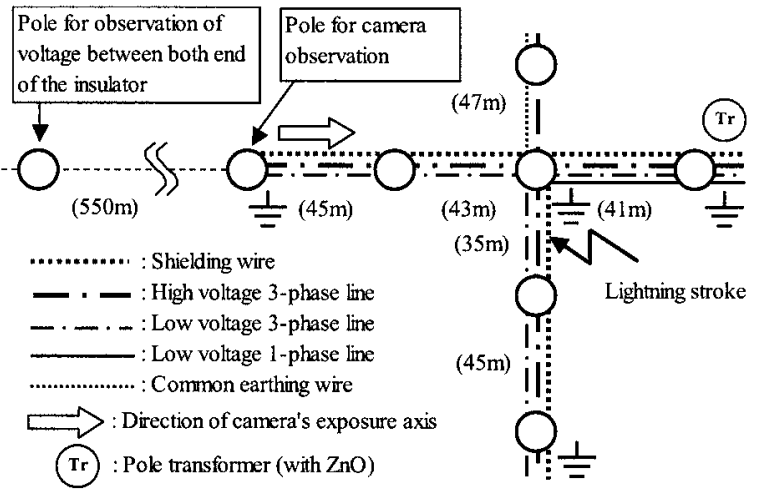

Note. Each symbols used in this figure has same meaning in following section

図 4 観測現場付近図

Fig. 4. Illustration of conditions of observation point.

- 多重度 : 1

- LPATS 推定電流值 : $-16.16 \mathrm{kA}$

(2) カメラ観測結果観測写真において雷放電路が 空中で終端しているが，これは配電線の上部に架線してい る架空地線に落雷したためである。観測写真より，雷放電 路は上方より進展してきた後, 配電線の近傍にて架空地線 に吸引されたようにも見える。また，この観測写真におい ては, 雷撃箇所付近のどこにも碍子や機器の絶縁破壊によ るアーク放電の発光箇所が見られず，また先に述べたとお り，この雷撃と同時刻の変電所リレーの動作がなかったこ とより，この直撃雷では線路の絶縁破壊は発生しなかった ものと推察できる。

(3) 雷サージ波形観測結果图 4 に示す観測装置で 落雷と同時に取得された雷サージ電圧波形の樣相を図 5 に 示す。なお，波形グラフにおいて OUT, MID , IN は, 光 れ光れ三相水平配列の家側・中央・道路側を表す (以下の 波形グラフにおいても同樣)。この観測事例において取得さ れたサージ電圧波形の波高値は $20 \mathrm{kV}$ 以下であり，配電線 の絶縁レベル $($ LIWV60〜 $100 \mathrm{kV})$ と比較すると小さい值で あるが , これは雷撃点と観測点が $600 \mathrm{~m}$ 以上離れており， サージが伝搬する過程で波高值が減衰したためと思われる。

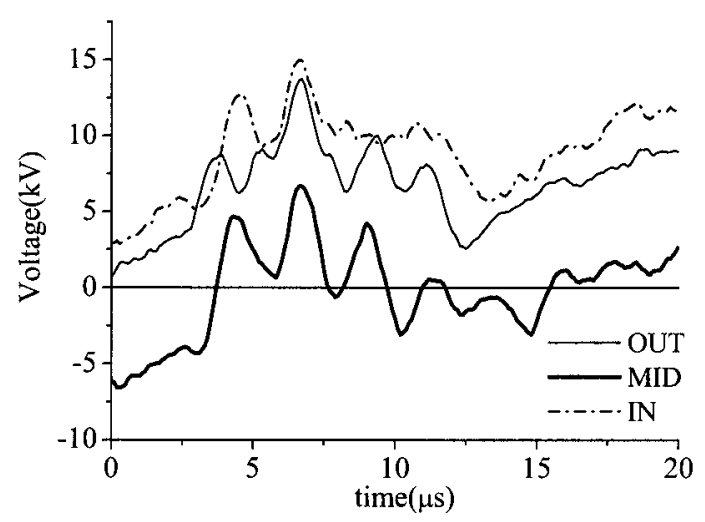

図 5 碍子間電圧波形

Fig. 5. Surge voltage waveform at the measuring point.

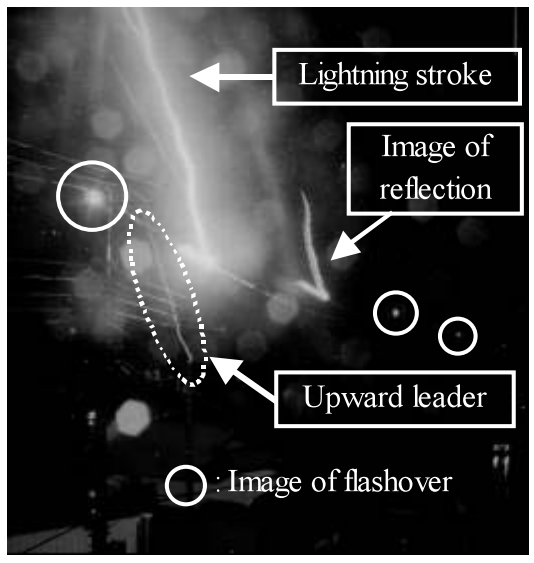

图 6 直撃雷観測写真炎の 2

Fig. 6. Photograph of direct stroke \#2.

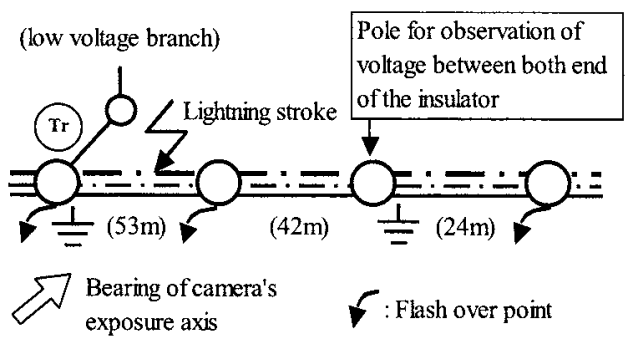

図 7 観測現場付近図

Fig. 7. Illustration of conditions of observation point.

なお, 図 5 において, 時刻 0 における三相交流の電圧和が 0 となっていないが , これはプレトリガ部に重畳している 先駆放電によると思われるノイズの影響である。

〈3. 2〉 直撃雷観測事例@落雷の樣子をとらえた写真 を図 6 に, 観測現場の概況図を図 7 に示す。雷観測カメラ および雷波形観測装置の GPS 時計による雷撃時刻は, 2000 年 7 月 18 日 22:35:13 であった。なお，この雷撃と同時刻 の変電所リレー動作はなかった。

（1）LPATS 標定データカメラおよび雷波形観測装 置の GPS 時計による雷撃時刻と一致する LPATS 標定デー タを以下に示す。 
- 標定位置 : 雷撃点の北方約 $460 \mathrm{~m}$

- 多重度 : 1

- 推定電流值 : $-41.5 \mathrm{kA}$

(2) カメラ観測結果 雷撃はカメラ設置柱の道路反 対側配電線の家相 (図 6 における水平配列の左相) 導体へ の落雷で, 落雷点近傍の電柱 3 基で家相碍子部分のフラッ シオーバが確認できる。一方, この落雷と同時刻の変電所 リレーの動作履歴がなかったことより以下のことが推察さ れる。すなわち, $6 \mathrm{kV}$ 配電系統の变電所中性点が非接地で あり，1 相のみの地絡電流は数 $\mathrm{A}$ 程度と小さいため, 地絡 リレー動作前に続流アークが自然消弧したものである。

さらに，観測写真から確認できる本事例の特徵を以下に 記す。

(1) 電線被覆沿面での放電＼cjkstart配電線の電力線には被覆絶 縁電線が使用されているが, 写真では落雷点から数 $\mathrm{m}$ 程度, 放電路が電線被覆沿面を走った後，被覆の中に入っている 樣子か確認できる。後日の現場調査の結果, 放電路が被覆 に入った箇所にピンホールが確認された。

(2) 落雷点近傍設備からの上向きリーダー進展 雷撃の あった配電線路からは低圧線が分岐しているが, 分岐第 1 柱の頂部から上向きのリーダーが進展している樣子か確認 できる。これより，ファイナル・ジャンプの過程において は, 電力線からの上向きリーダーの方が, 低圧柱からのリー ダーよりも先に上空からのステップトリーダーと結合した と考えられる。

(3) 雷サージ波形観測結果＼cjkstart图 7 に示す観測装置で 落雷と同時に取得された碍子間電圧波形の樣相を図 8 に示 す。なお, 各相電圧のファーストピーク最大値は, 家相 : $-150 \mathrm{kV}$ (ただし観測レンジ振り切れ), 中相 : $-40 \mathrm{kV}$, 道 相 : $-30 \mathrm{kV}$ であり, 雷撃相の家相に, 誘導相の中相・道相 に比へて高い電圧が発生していることも観測写真と合致す るデータである。また，先に述べたとおり本事例において は変電所リレーの動作履歴は無いが, 観測波形データにお ける低速サンプリング波形 (20 ms までのフルレンジ波形) においても商用周波の常規碍子間電圧 $(\fallingdotseq 5.4 \mathrm{kV})$ が維持 されていることが確認できる。

〈3. 3〉直撃雷観測事例(3 落雷の樣子をとらえた写 真を图 9 に，観測現場の概況図を图 10 に示す。雷観測力 メラおよび雷波形観測装置の GPS 時計による雷撃時刻は, 1999 年 9 月 1 日 17:07:08 であつた。この雷撃により,配 電線に短絡が生じ, 変電所の OCR (過電流保護リレー) 動 作により一時的に遮断器が開放したが, 遮断器の再投入が 成功したため供給支障とはならなかった。

(1) LPATS 標定データ カメラおよび雷波形観測装 置の GPS 時計による雷撃時刻と一致する LPATS 標定デー タを以下に示す。

-標定位置 : 雷撃柱の北方約 $320 \mathrm{~m}$

-多重度 : 1

- 推定電流値 : $-13.5 \mathrm{kA}$

（2） カメラ観測結果 写真の雷撃はカメラ観測柱よ

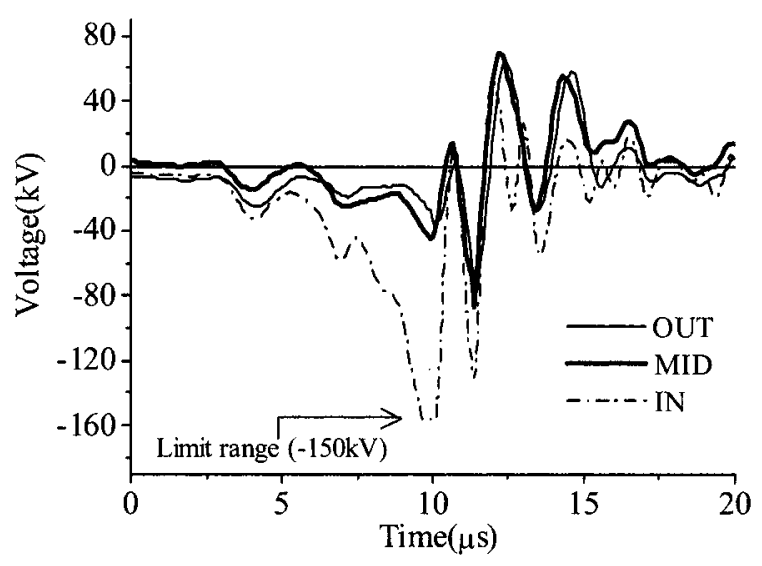

(a) Waveform in short time range

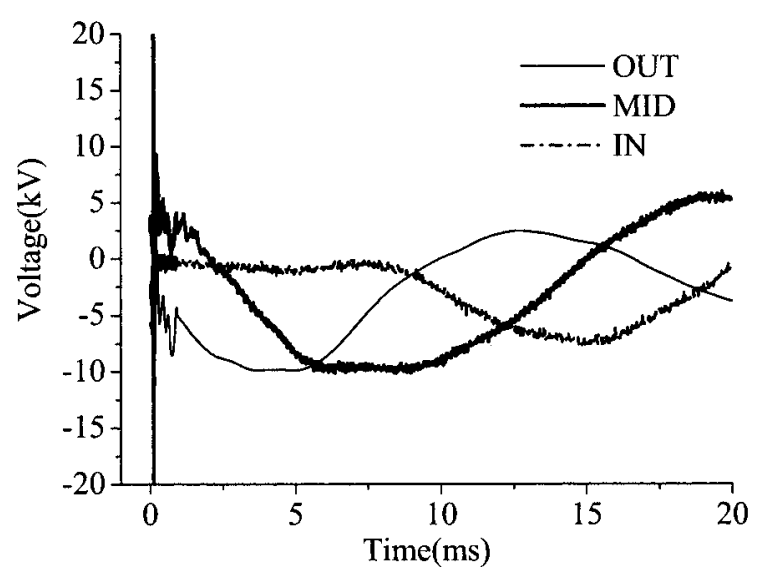

(b) Waveform in full time range

図 8 碍子間電圧波形

Fig. 8. Surge voltage waveform at the measuring point.

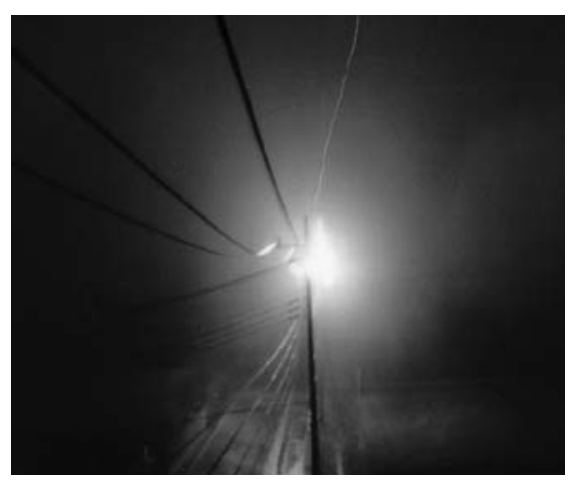

图 9 直撃雷観測写真光の 3

Fig. 9. Photograph of direct stroke \#3.

り 2 基先の電柱頂部への落雷である。東京電力における $6 \mathrm{kV}$ 配電線の電線支持がいし部には, 雷撃時の絶縁破壊に 続く交流アーク続流による断線を防止するための「放電ク ランプ(8)」と呼ばれる放電極力設けられており，観測写真に おいて雷撃柱に見られる強い発光は, この放電クランプ部 分での交流アーク放電光である。後日の現場調査では, 雷 撃柱の家相と道相 (図 9 の電線配列における右相と左相) にアーク痕が確認された。なお, 当該配電線には架空地線 は施設されていない。 


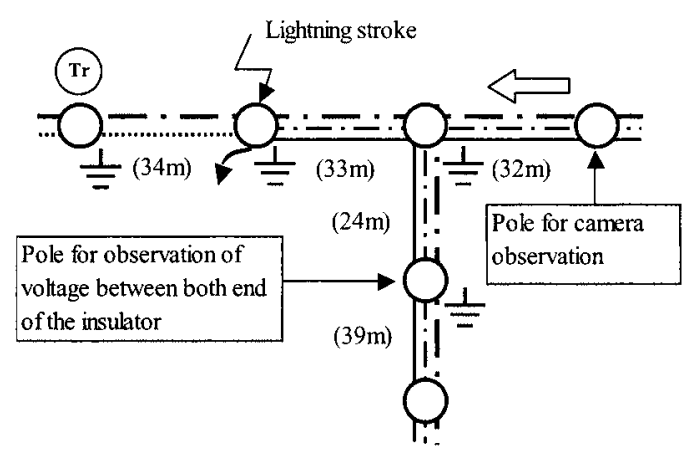

図 10 観測装置の設置状況

Fig. 10. Illustration of conditions of observation point.

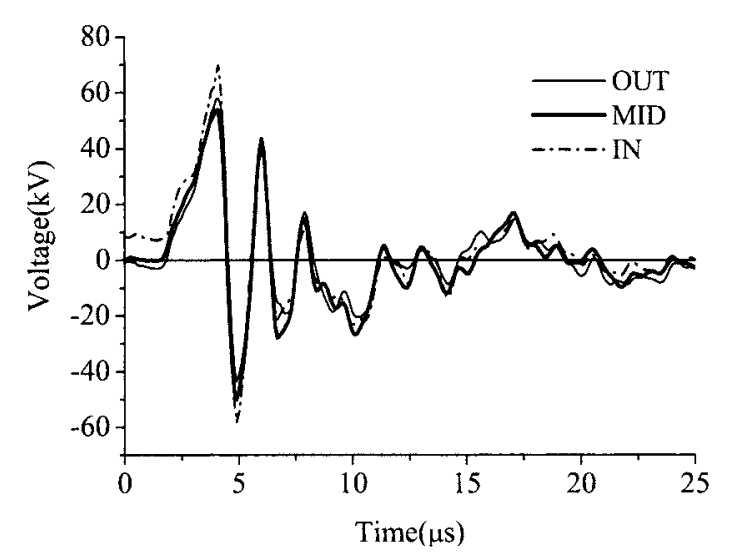

(a) Waveform in short time range

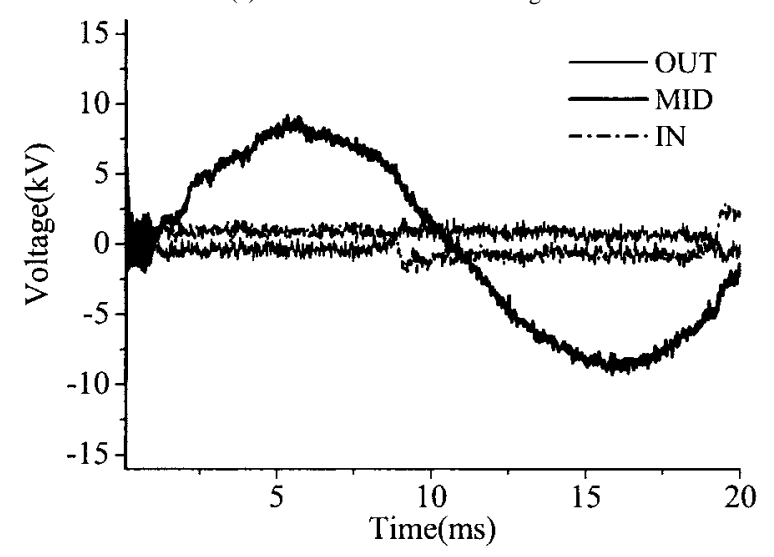

(b) Waveform in full time range

图 11 碍子間電圧波形

Fig. 11. Surge voltage waveform at the measuring point.

（3）雷サージ波形観測結果图 10 に示す雷サージ波 形観測装置で取得された碍子間電圧波形データを図 11 に 示す。同図 (a) では高速サンプリング波形を $25 \mu \mathrm{s}$ まで示 しており，電圧波高值は 69.9 (kV) (家相) であった。同 図 (b) では，20 ms までの低速サンプリング波形を示して おり, 波形データの後半部分で商用周波電圧が約 1 周期分 確認できるようになっている。同図 (b) に示す商用周波領 域までを含む波形においては，家相と道相の波形が常規碍 子間電圧 $(\fallingdotseq 5.4 \mathrm{kV})$ にくらべてほぼ零近くまで低下して

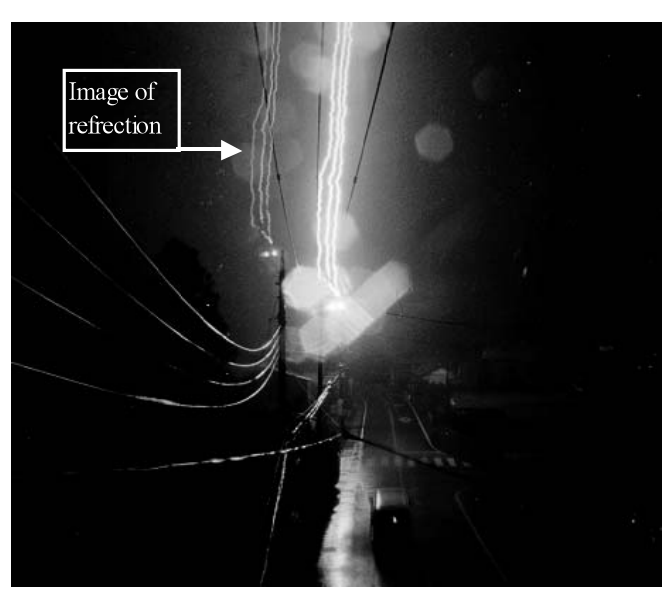

図 12 直撃雷観測写真光の 4

Fig. 12. Photograph of direct stroke \#4.

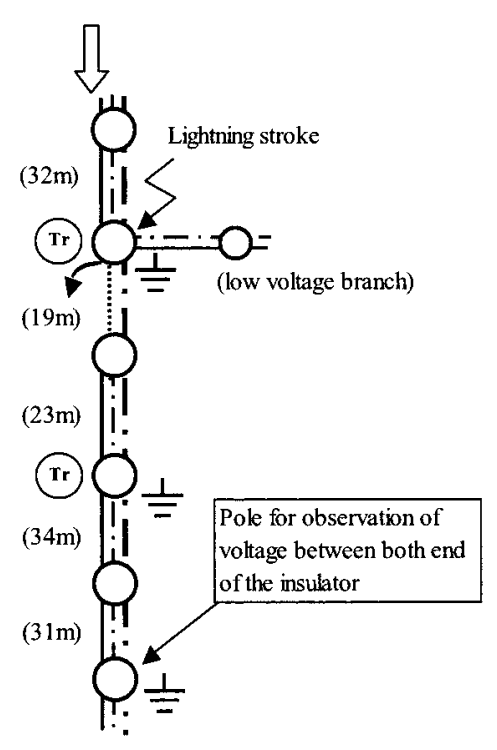

図 13 観測現場付近図

Fig. 13. Illustration of conditions of observation point.

いるが，これは碍子閃絡に続く交流アークにより電力線 腕金間が短絡状態となっているためであり，このことは現 場調査時に家相・道相にアーク痕が発見された事実にも合 致する。一方，同図 (a) に示す電圧波形の波頭部において は, 3 相とも同樣の波形変化を示しながらほぼ零へと推移 しており，これより，この時点においては 3 相ともに閃絡 が発生したと推察される。すなわち本事例は，電柱頂部人 の雷撃により 3 相とも逆閃絡が発生したが, 中相において は, 放電経路に続流アークが継続せずに自然消弧した可能 性を示唆している。

〈3. 4〉 直撃雷観測事例(4)落雷の樣子をとらえた写 真を図 12 に，観測現場の概況図を图 13 に示す。雷観測力 メラおよび雷波形観測装置の GPS 時計による雷撃時刻は， 1999 年 7 月 25 日 18:47:42であった。この雷撃により,配 電線に短絡が生じ, 变電所の OCR (過電流保護リレー) 動 作により一時的に遮断器が開放したが, 遮断器の再投入が 
表 1 多重雷の LPATS 標定データ

Table 1. Data of multi strokes by LPATS.

\begin{tabular}{|l|l|l|l|}
\hline & $\begin{array}{l}\text { Time of lightning } \\
\text { striking [s] } \\
\text { (indicated sixth } \\
\text { decimal place) }\end{array}$ & $\begin{array}{l}\text { Difference of } \\
\text { striking time }\end{array}$ & $\begin{array}{l}\text { Current } \\
\text { value } \\
\text { esimated by } \\
\text { LPATS }\end{array}$ \\
\hline 1st Stroke & .272619 & & $-35.35 \mathrm{kA}$ \\
\hline 2nd & .312111 & $39.492 \mathrm{~ms}$ & $-13.76 \mathrm{kA}$ \\
\hline 3rd & .384256 & $72.145 \mathrm{~ms}$ & $-27.83 \mathrm{kA}$ \\
\hline 4th & .481673 & $97.417 \mathrm{~ms}$ & $-12.26 \mathrm{kA}$ \\
\hline
\end{tabular}

成功したため供給支障とはならなかった。

（1）LPATS 標定データ カメラおよび雷波形観測装 置の GPS 時計による雷撃時刻と一致する LPATS 標定デー タを以下に示す。

・標定位置 : 雷撃柱の北西約 $180 \mathrm{~m}$ (下記 4 データの中 心点と雷撃柱の距離)

- 多重度 : 4

- 推定電流値 : $1 \mathrm{st}:-35.35 \mathrm{kA}, 2 \mathrm{nd}:-13.76 \mathrm{kA}$, 3rd: $-27.83 \mathrm{kA}, 4 \mathrm{th}:-12.26 \mathrm{kA}$,

なお，各雷撃の詳細な時刻データを表 1 に示す。

(2) カメラ観測結果写真の雷撃はカメラ設置柱よ り 3 基先の電柱への落雷である。写真から観測できる雷放 電路は 3 本であるが , 写真と同時刻の LPATS 標定位置デー 夕は上記の $4 つ$ (雷撃地点から最近点 $=$ 約 $140 \mathrm{~m}$, 最遠点 $=$ 約 $200 \mathrm{~m}$ ) であり，かつ 4 つの位置標定データが半径約 $50 \mathrm{~m}$ の円内に収まることから, 同一箇所 (柱頂部) への雷 撃であったと判断し，多重度を 4 とした。

また同写真の雷撃柱の家相と中相の碍子部分に続流アー クの発光点が 2 つ確認できる。後日の現場調査では, 雷撃 柱の家相と中相にアーク痕が確認されており，この現場調 査結果は観測データを裏付けるものである

(3) 雷サージ波形観測結果＼cjkstart図 13 に示す観測装置で 落雷と同時に取得された碍子間電圧波形の樣相を図 14 に

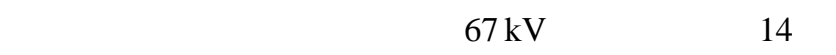
は, 図 11 と同樣に, (a) に $25 \mu \mathrm{s}$ までの高速サンプリング 波形を,(b) にフルレンジである $20 \mathrm{~ms}$ までの低速サンプリ ング波形を連続して示しているため, 波形データ後半部分 の商用周波電圧が約 1 周期分確認できる。

図 14 に示す波形データのトリガ時刻の秒以下は， $\ulcorner .272621\lrcorner$ であり，表 1 の落雷時刻を比較すると，波形デー 夕は第一雷撃のものであったと想定される。(a)の高速サン プリング波形においては, 時刻 $6 \mu \mathrm{s}$ 付近において直撃雷観 測例(3の波形と同樣，三相が同時に負極性に触れているた めこの時点で逆閃絡が発生したと推察される。一方，(b)に 示す波形データ後半の低速サンプリング波形より, 商用周 波の常規碍子間電圧 $(\fallingdotseq 5.4 \mathrm{kV})$ が維持されており先の直 撃雷観測事例(3の波形に見られたような電圧ドロップは発 生していないことが確認できるので，このデータ採取時間 内では続流アークによる短絡は継続せず消弧したと判断さ れる。すなわち，観測写真および現場調査で確認された家

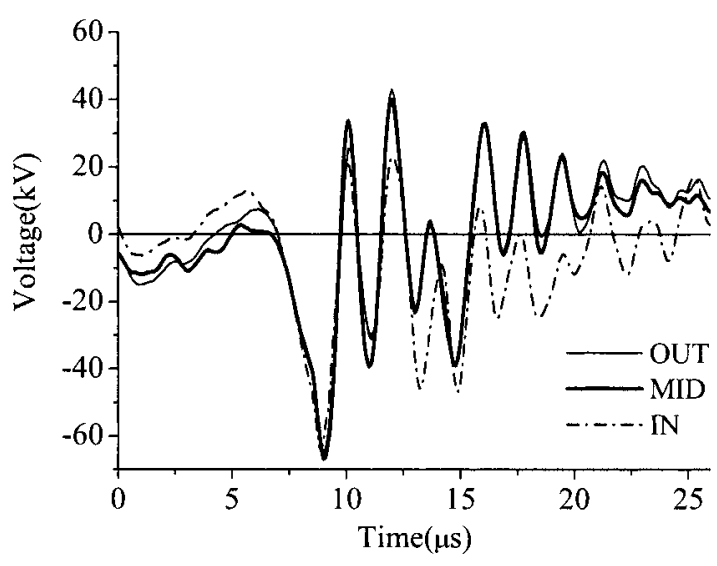

(a) Waveform in short time range

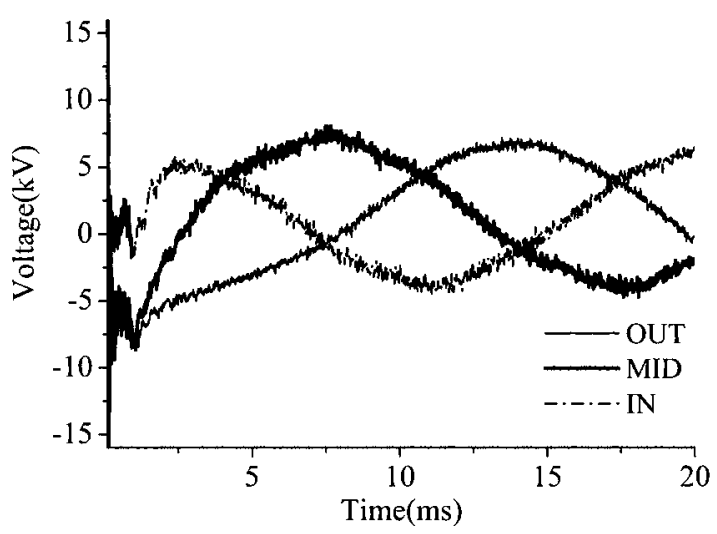

(b) Waveform in full time range

图 14 碍子間電圧波形

Fig. 14. Surge voltage waveform at the measuring point.

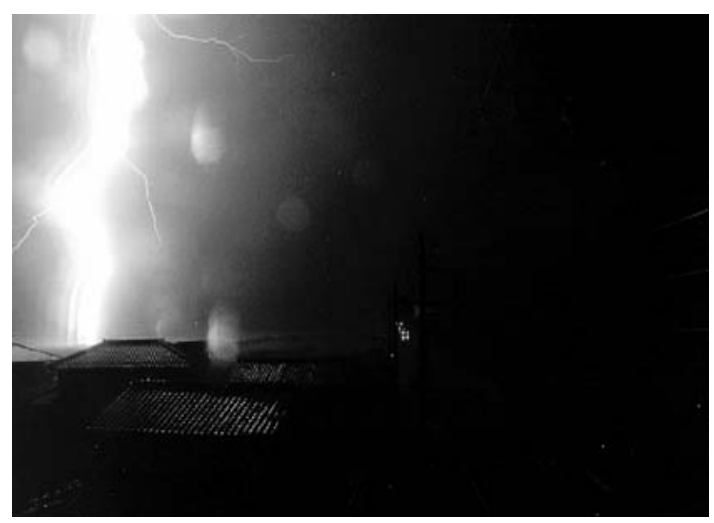

図 15 誘導雷 (配電線近傍落雷) 観測写真

Fig. 15. Photograph of nearby stroke.

相・中相の続流アークは, 第 1 雷撃ではなく後続の第 2 雷 撃以降で発生したと考えることが妥当である。

〈3.5〉誘導雷観測事例落雷の樣子をとらえた写真を 図 15 に, 観測現場の概況図を図 16 に示す。雷観測カメラ および雷波形観測装置の GPS 時計による雷撃時刻は, 1998 年 7 月 29 日 23:31:48 であった。なお，この雷撃と同時刻 の変電所リレー動作はなかった。

（1） LPATS 標定データカメラおよび雷波形観測装 


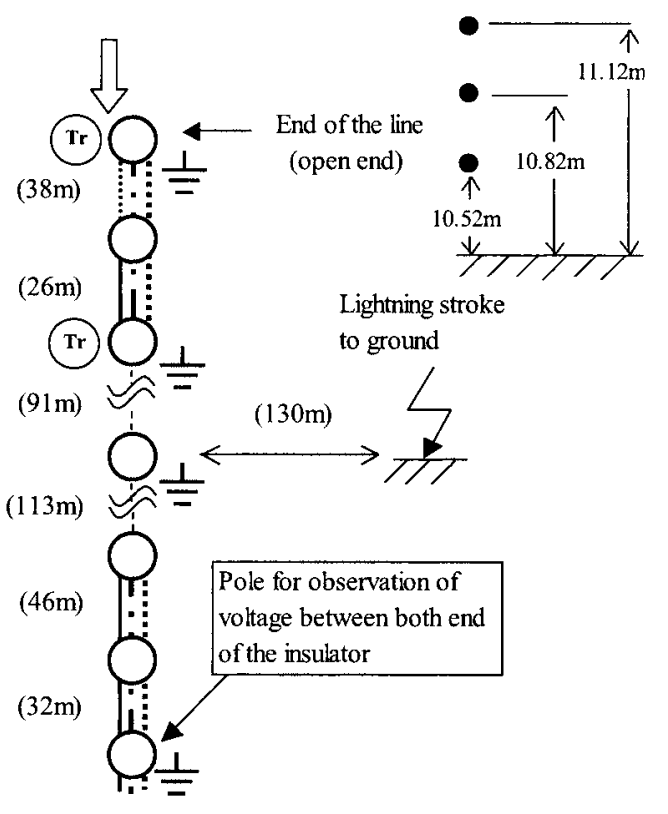

図 16 観測装置の設置状況

Fig. 16. Illustration of conditions of observation point.

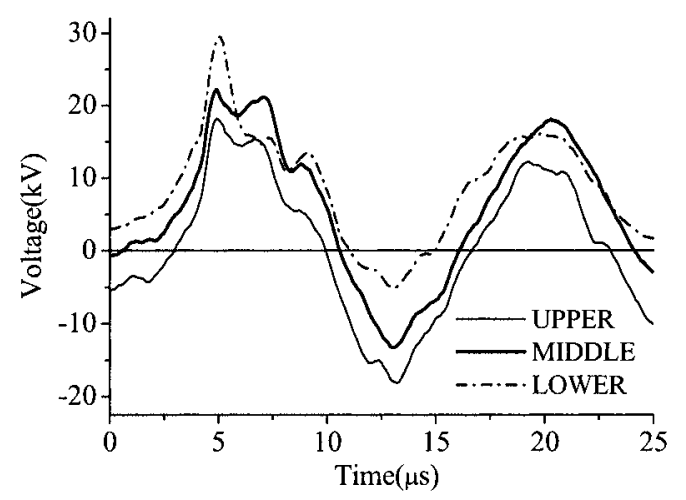

図 17 碍子間電圧波形

Fig. 17. Surge voltage waveform at the measuring point.

置の GPS 時計による雷撃時刻と一致する LPATS 標定デー タを以下に示す。

- 標定位置 : 落雷点の北北西約 $400 \mathrm{~m}$

- 多重度 : 1

- 推定電流値 : $-18.15 \mathrm{kA}$

(2) カメラ観測結果観測写真と, 昼間の現場付近 の写真との比較より, 落雷は配電線路から約 $130 \mathrm{~m}$ 離れた 水田への落雷であったことが判明した。この観測写真にお いては, 先の直撃雷観測事例(1)同樣に閃絡を示唆する発 光箇所は見られず,また，この雷撃と同時刻の変電所リレー の動作がなかったことより，この誘導雷では線路の絶縁破 壞は発生しなかったものと推察できる。

(3) 雷サージ波形観測結果図 16 に示す観測装置 で落雷と同時に取得された雷サージ電圧波形の樣相を図 17 に示す。観測実施箇所付近の配電線路は, 電力線を上・中・ 下に垂直配列した装柱 (図 16 参照) となっているが，観
測された誘導雷過電圧の波高値は, 上相が他相に比較して 若干高いものの，三相で大きく異なってはいない。大地を 完全導体と仮定して, 雷放電に伴う大地に垂直な電界成分 に基づき誘導雷電圧を計算する手法 ${ }^{(9)}$ においては, 配電線 路程度の地上高で発生する誘導雷サージの電気的誘導成分 es および磁気的誘導成分 em は, ともに地表面における垂 直電界成分に線路地上高 $\mathrm{h}$ を乗じて近似的に計算されるた め, 定性的には地上高の高い線路の方が, 誘導過電圧も大 きくなるはずであるが, 実測誘導雷サージの波高値が三相 で光れほど変わらないのは, (1)大地が有限の導電率を有す ること，(2)実線路には機器や避雷器が多数接続されている こと，(3)分岐や末端からの反射が複雑に重畳すること，等 の影響が波形に表れることが考えられる。

\section{4. 観測結果の考察}

上記 5 例の雷撃樣相総合観測結果より得られた，今後の 配電線の耐雷設計合理化に資すると思われる新たな知見に ついて以下に詳述し，概要を表 2 にとりまとめる。

〈 4 1〉 直撃雷に対する配電線の耐雷性能 従来, 配電 線の絶縁レベルでは直撃雷保護はほぼ不可能と考えられて いたが, 実配電線における観測では, 直撃雷観測事例(1のよ うに, 直撃雷発生時にも閃絡か確認されない事例があった。 このことは, 耐雷機材を適切に組み合わせることで, 配電 線の直撃雷保護もある程度可能とする最近の実験結果 ${ }^{(10)}$ と も合致する。一方，直撃雷観測事例(3)，(4)のように雷撃に より碍子部分での閃絡が発生し, 閃絡箇所に交流続流が継 続した場合であっても，断線防止機材 (放電クランプ) の動 作により，線路絶縁の自復性が保たれたため，再送電は全 て成功し電力の供給支障とはならなかった。また，直撃雷 観測事例のケースでは, 電力線に直接落雷したため, 雷 撃点直近柱に施設された柱上変圧器には他の観測例の場合 よりも大きな雷サージが侵入したと推察されるが, 変圧器 に内蔵された耐雷素子により機器内部の絶縁破壊か防止さ れ，配電線事故は発生しなかった。

このように，耐雷機材の普及した現在の配電線は, 誘導 雷のみならず直撃雷に対してもある程度の耐雷性を有して いると考えられる。

〈4. 2〉 配電線雷事故発生のメカニズム雷撃から事故 発生 (変電所リレーの動作) に至るまでの配電線の挙動を 把握することは, 事故率の予測をする上で極めて重要であ る。以下に, 本観測から得られた配電線事故発生のメカニ ズムに関わる知見を述べる

（1） 1 相閃絡 (地絡） 直撃雷観測事例(2)(被覆絶縁 電線への雷撃) においては, 雷撃相にのみ碍子閃絡が確認 された。このケースでは 1 相のみ地絡となるが，一般的な 中性点非接地配電線では放電経路に交流続流が継続しない ため, 変電所リレーは動作しなかった。このことは, 従来 非接地系固有の事象として取り上げられ, 配電線雷事故率 計算手法に反映されていたが(3)，本観測により実配電線に おいて同現象が起きていることが初めて確認された。 
表 2 観測事例の考察結果一覧

Table 2. Summery of the investigations of observation data.

\begin{tabular}{l|l|l|l|l|l}
\hline Case & Type of lightning & Lightning striking point & $\begin{array}{l}\text { Substation's } \\
\text { relay operation }\end{array}$ & $\begin{array}{l}\text { Flash over } \\
\text { generation }\end{array}$ & \multicolumn{1}{|c}{ REMARKS } \\
\hline No.1 & Direct stroke & Shilding wire & (no operation) & (no F.O) & - Shilding wire probably prevented the flashover generation. \\
\hline No.2 & Direct stroke & Power conductor & (no operation) & in one phase & $\begin{array}{l}\text { - This example confirms that the one phase flashover does not } \\
\text { cause the fault. }\end{array}$ \\
\hline No.3 & Direct stroke & Top pf pole & OCR & in three phase & $\begin{array}{l}\text { Lightning protective equipments in fields prevent serious } \\
\text { damages of distribution lines cven if flashover occurs. } \\
\text { - This example suggests that AC current following flashover is } \\
\text { spontaneously extinguished. }\end{array}$ \\
\hline No.4 & Direct stroke & Top of pole & OCR & in three phase & $\begin{array}{l}\text { - This example suggests that distribution line's faults may be } \\
\text { caused by following stroke of multi lightning stroke. }\end{array}$ \\
\hline No.5 & Nearby syroke & Ground(130m from the line) & (no operation) & (no F.O) & \\
\hline
\end{tabular}

(2) 多相閃絡 (短絡) 配電線の碍子部分で多相閃絡 が発生すると，腕金を介して異相地絡の経路が繋がるため 短絡に移行する。直撃雷観測事例(3)，(4)においては，配電 柱への雷撃により 3 相逆閃絡が発生し碍子間電圧が一旦ほ ぼ零に低下したが , 閃絡が発生した後の商用周波の波形に おいては，(3)のケースで1 相 (中相)，(4)のケースでは 3 相 全てで常規対地電圧が復帰していることか確認された。こ のことは, 配電線において雷による多相閃絡が発生し, 短 絡状態に移行した後に, 放電経路の交流続流アークか継続 せずに自然消弧する可能性を示唆している。従来の事故率 計算手法では, 多相閃絡後の交流続流は消弧しない，すな わち必ず変電所リレー動作に至るものとして計算すること が一般的であるので, 事故率計算精度を向上する上で, 続 流の消弧はその影響を考慮すべき現象であると考えられる。

〈4 3〉多重雷撃時の配電線の挙動 直撃雷観測事例(4) においては,波形データの取得時刻と LPATS 標定時刻との 比較より, 変電所リレーの動作に至った雷撃は第 2 雷撃以 降であると推察した。第一雷撃により発生した閃絡経路の アーク続流が自然消弧したのに対して，第二雷撃以降で発 生した閃絡経路にアーク続流が継続した理由は不明である が, 多重雷における第二雷撃以降の後続雷撃の電気特性は, 第一雷撃とは異なっていることが知られているため ${ }^{(1)}$, 本 観測結果は, フィールドの雷事故発生率を精度良く把握す るためには, 後続雷撃の性状を考慮した多重雷の影響も確 認する必要があることを示唆している。

\section{5. まとめ}

実配電線にて実施した雷撃樣相の総合観測により，1996 年から 2000 年の間に得られた特徵的な観測事例について， 弚の概要と得られたデータの考察結果について述べた。

本論文の要約について以下に記す。

（1）従来，配電線の絶縁レベルでは直撃雷保護はほぼ 不可能と考えられていたが, 耐雷機材が普及した現在の配 電線は誘導雷のみならず直撃雷に対してもある程度の耐雷 性を有する。

（2）雷撃による碍子閃絡後，2 相以上で続流が継続し
た場合に配電線事故 (変電所リレ一動作) となる。この際， 雷撃発生時に多相閃絡が発生しても，続流アークが消弧し て, 変電所リレー動作に至らない場合もありうる。

（3）多重雷撃の場合，第 1 雷撃で事故に至らなくても 第 2 雷撃以降の閃絡により,配電線事故に至る場合がある。

今後は, 本検討結果基づいて，フィールドにおける直撃 雷/誘導雷の発生頻度や, 雷撃時の発生過電圧・接地線電流 の分布等の雷統計データについて分析を進め, 配電線耐雷 設計のより一層の合理化に取り組む予定である。

(平成 15 年 9 月 25 日受付, 平成 16 年 1 月 21 日再受付)

$$
\text { 文献 }
$$

(1) Subcommittee for Power Distribution Systems, Lightning Protection Design Committee: "Guide of Lightning Protection Design for Power Distribution Systems", Technical Report of CRIEPI, No.T69 (2002) (in Japanese) 耐雷設計委員会配電分科会 :「配電線耐雷設計ガイド」, 電中研総合 報告, No.T69 (2002)

(2) IEEE WG: "A simplified method for estimating lightning performance of transmission lines", IEEE84, SM698-7 (1984)

(3) A. Asakawa, S. Yokoyama, and Y. Hashimoto: "Development of the Analytical Method for the Outage Ratio Due to Lightning on Power Distribution Lines (Part 1)", Technical Report in CRIEPI, No.T92087 (1993) (in Japanese)

浅川 聡・横山 茂・橋本洋助：「配電線雷事故率計算手法の開発 (弚の 1) 」, 電中研研究報告, No.T92087 (1993)

( 4 ) H. Taniguti, H. Sugimoto, and S. Yokoyama: "Observation of Lightning Performance on Power Distribution Line by Still Cameras", T. IEE Japan, Vol.116-B, No.9, pp.1138-1143 (1996-9) (in Japanese)

谷口弘光・杉本仁志・横山 茂: 「配電線雷撃応答樣相のカメラ観 測」, 電学論 B, 116, 9, pp.1138-1143 (1996-9)

( 5 ) T. Takinami, T. Hirai, T. Chindo, T. Yamada, Y. Shiraishi, S. Amemiya, and K. Mizumoto: "Development of Optical Voltage Sensor for Lightning Surge Monitoring Equipment”, 1999 National Convention Record IEE Japan, No.1717 (1999) (in Japanese)

滝波 力・平井崇夫 ·珎道拓治 - 山田剛史 - 白石康寛 ·雨宮慎治 . 水本州彦：「配電線雷波形観測装置用光電圧センサの開発」, 平成 11 年電気学会全国大会, No.1717 (1999)

(6) T. Hirai, T. Takinami, and S. Okabe: "Observation of Lightning Phenomena on Real Distribution Lines”, 電気学会放電 ·開閉保護 $\cdot$ 高電圧合同研 資, HV-01-94 (2001)

(7) T. Shioda, T. Narita, E. Zaima, and M. Ishii: "Performance Evaluation of LPATS-T at TEPCO”, 25th International Conference on Lightning Protection, No.2.1 (2000)

( 8 ) H. Yamamoto, T. Minejima, I. Sumitani, S. Kojima, T. Fukano, and T. Tada: "Prospective Method of Lightning Protection Schemes in Distribution System", T. IEE Japan, Vol.117-B, No.10, pp.1345-1352 (1997-10) (in Japanese)

山本秀幸 ·峰島俊哉. 炭谷一朗 - 小島宗次 . 深野孝人 . 多田孝光 : 
「高圧配電線における今後の耐雷方策の一手法」, 電学論 B, 117, 10, pp.1345-1352 (1997-10)

(9) S. Rusch: "Induced lightning over-voltage on power transmission lines with special reference to the overvoltage protection of low-voltage networks", Trans. Royal Institute of Technology, No.120 (1958)

(10) S. Yokoyama and A. Asakawa: "Experimental Study of Direct Lightning Hits on Power Distribution Lines", Technical Report in CRIEPI, No.T87086 (1988) (in Japanese)

横山 茂・浅川 聡:「配電線の直撃雷応答特性の実験的検討」, 電 中研研究報告, No.T87086 (1988)

(11) K. Berger, R.B. Anderson, and H. Kroninger: "Parameter of lightning flashes", CIGRE Electra, No.41, pp.23-27 (1975)

平井崇 夫

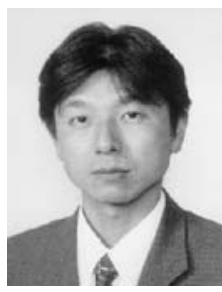

正員) 1991 年 3 月早稲田大学理工学部電子通 信学科卒業。同年 4 月, 東京電力 (株) 入社。現 在 , 電力技術研究所所属。主として配電系統の雷 観測・サージ解析に関する研究に従事。

岡 部 成 光 (正員) 1986 年 3 月東京大学大学院工学研究科

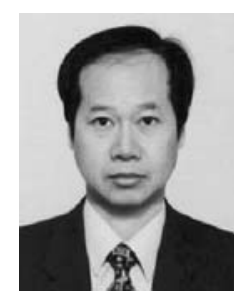

電気工学専攻博士課程修了。同 4 月，東京電力

(株) 入社。1992 年ミュンヘン工科大学客員研究 員。現在 , 技術開発研究所絶縁技術グループ。エ 学博士。IEEE 会員。
滝 波 力 (正員) 1993 年 3 月早稲田大学大学院理工学研

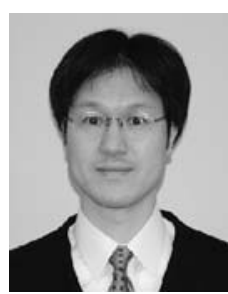
究科電気工学専攻博士前期課程修了。同年 4 月東 京電力 (株) 入社。現在, 銀座支店配電部配電建 設グループに勤務。技術開発研究所 (旧電力技術 研究所) 在籍時に配電線雷観測研究に従事。

珎 道 拓 治 (正員) 1989 年 3 月早稲田大学理工学部電気工学

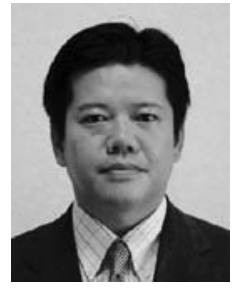
科卒業。同年 4 月, 東京電力 (株) 入社。現在， 東京電力配電部配電機材技術センター品質管理グ ループに勤務。技術開発研究所 (旧電力技術研究 所) 在籍時に配電線雷観測研究に従事。 